\title{
BIOREFINERIES - FACTORIES OF THE FUTURE
}

\author{
Andrzej B. Kołtuniewicz*, Katarzyna Dąbkowska \\ Warsaw University of Technology, Faculty of Chemical and Process Engineering, Waryńskiego 1, \\ 00-645 Warsaw, Poland
}

\section{Dedicated to Prof. Ryszard Pohorecki on the occasion of his 80th birthday}

\begin{abstract}
Efforts were made to demonstrate that in biorefineries it is possible to manufacture all the commodities required for maintaining human civilisation on the current level. Biorefineries are based on processing biomass resulting from photosynthesis. From sugars, oils and proteins, a variety of food, feed, nutrients, pharmaceuticals, polymers, chemicals and fuels can further be produced. Production in biorefineries must be based on a few rules to fulfil sustainable development: all raw materials are derived from biomass, all products are biodegradable and production methods are in accordance with the principles of Green Chemistry and Clean Technology. The paper presents a summary of state-of-the-art concerning biorefineries, production methods and product range of leading companies in the world that are already implemented. Potential risks caused by the development of biorefineries, such as: insecurities of food and feed production, uncontrolled changes in global production profiles, monocultures, eutrophication, etc., were also highlighted in this paper. It was stressed that the sustainable development is not only an alternative point of view but is our condition to survive.
\end{abstract}

Keywords: sustainable development, biorefineries, biotechnology, clean technologies, green chemistry

\section{INTRODUCTION}

Biorefineries are factories that use renewable raw materials as substrates to produce various necessary products, which temporary are made from fossil fuels. They are indispensable in the future because the total amount of fossil resources on the Earth is finite. On the other hand, it is obvious that solar energy that reaches the Earth can be used for many years. Photosynthesis is a most useful phenomenon for sustaining life on the Earth that enables the production of substances necessary for a many species and allows for the maintenance of "web of life". Photosynthesis is very beneficial because it maintains a high level of oxygen in the atmosphere and contributes to the increase in the amount of organic carbon at the expense of inorganic matter. The efficiency of converting light energy into chemical bond energy of carbohydrates is $22-33 \%$. Using the language of physics, we must live according to the "conservation laws", in order to avoid depletion of resources or/and accumulation of pollutants. The inclusion of humanity in the web of life is the only way and the precondition for its survival on Earth. The International Energy Agency defined that: „Biorefinery is the processing of biomass into a variety of bio-based products as: food, feed, chemicals, and materials) and bioenergy (biofuels, electricity and/or heat) (Biopol, 2009). The latest achievements, made it possible to ensure sustainable production processes of different commodities from biomass (Fig.1). 

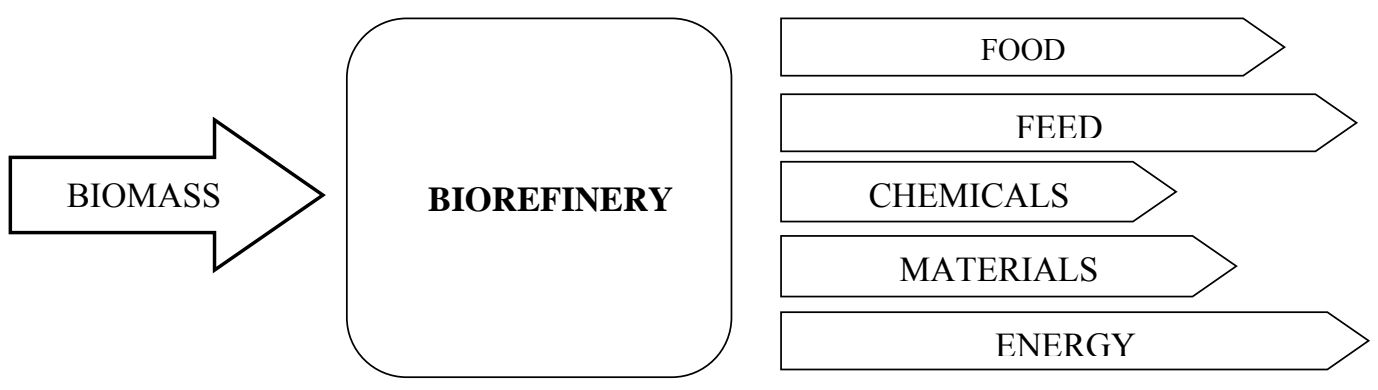

Fig. 1. Biorefinery concept (Koltuniewicz, 2014)

\section{BIOREFINERY PRINCIPLES}

In order to be realistic a biorefinery concept must meet the following principles: (i) all raw materials must come exclusively from the biomass, (ii) all products must be biodegradable, (iii) all processes must comply with Green Chemistry and Clean Technologies (Koltuniewicz, 2014).

The first principle means that all non-renewable raw materials are prohibited to eliminate resource depletion. The second principle excludes the production of so-called "xenobiotics" that are subject to continuous accumulation in the food chain of plants and animals, and are usually harmful for all. The ideal would be to make use of all the atoms on Earth in such a way as if there were still circulating in nature, before the industrial age. The third principle defines the acceptable means and production methods, and states that all waste must be converted to valuable products or energy, based on Green Chemistry and Clean Technologies that are widely known and accepted. The "Green Chemistry" is acting at the molecular level, which prevents the formation of xenobiotics, providing high production economy, and it is typically defined in a form of detailed rules (Koltuniewicz, 2014). The same effects give the principles of "Clean Technologies" that allow for the recovery and reuse all of the media and the energy during production. Clean Technologies are based on modern separation processes that also allow for additional energy savings (Koltuniewicz and Drioli, 2008).

These rules prevent contamination of the Earth, but also contribute to use much more components from biomass than now. It can be anticipated that following the application of these rules many different products will be produced in biorefineries at the same time. An advantage of this production method is also higher flexibility, when bulk products at a moderate price are counterbalanced by more expensive products produced in smaller quantities (see Fig. 2).

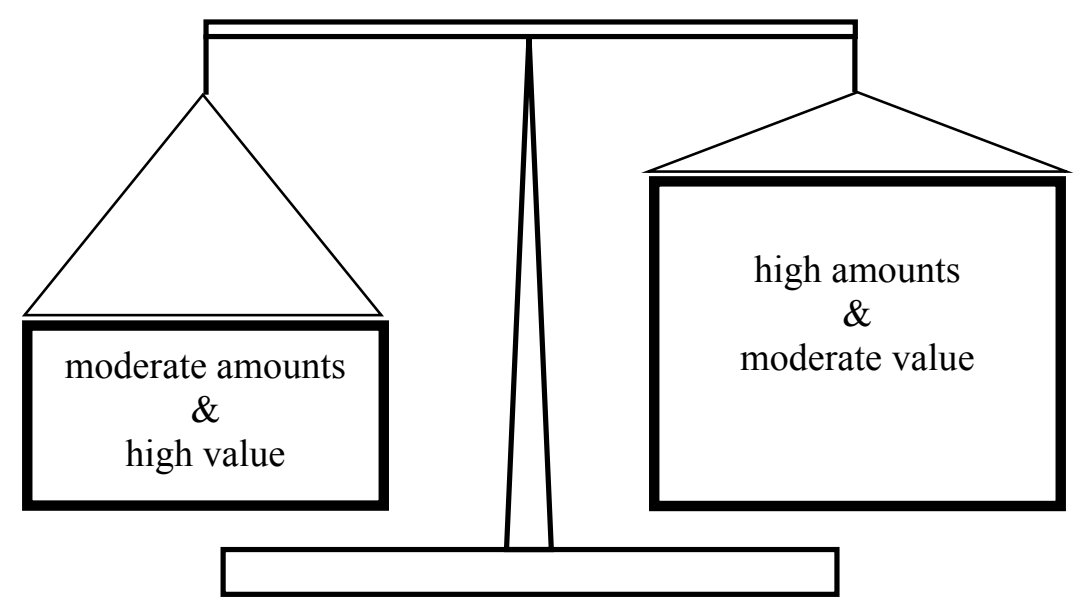

Fig. 2. Balancing of products with different values (Koltuniewicz, 2014) 
All indications are that biorefineries could contribute to achieving the high economic level, but in a slightly unconventional way. Compliance with physical conservation laws give us a more strategic approach than adapting to so called economic rights, which seem to be more short-sighted. It is easy to be achieved using the principles of Green Chemistry and Clean Technologies, where only pure substances are produced without waste. Byproducts can be easily used for other production or converted directly into energy, which also increases the profitability of production. Anyway, biorefineries should not produce only one selected product. This would create a threat to biodiversity, which can be limited by monocultures causing the depletion of essential nutrients, various diseases, soil degradation and even desertification of arable land. On the other hand, excessive fertilisation can lead to eutrophication. Therefore, it is better to rely on small producers who could diversify their production profiles and the types of raw materials that are suitable to local conditions. The best would be the use of biomass resulting from the production of different kinds of wastes such as food, paper, agricultural and wood wastes.

All of the rules seem to be very restrictive. However, it should be said that they relate to an ideal model that can be implemented gradually opening the way of development strategy. It is expected that lobbyists from various sectors will be the main opponents of biorefineries offering other more costeffective solutions for them but not for humanity as a whole.

The entire production in the future must be based on renewable raw materials, although just now there are reasons to develop biorefineries. There is also a growing demand among consumers for all natural products and especially the ingredients of the food industry, chemicals, pharmaceuticals, cosmetics and cleaning products (Regulation EC No 1334/2008). Today's consumers require new production methods that are non-invasive and harmless for live animals, in contrast to some traditionally manufactured products. It is also important that raw materials for biorefineries do not create competition for food and other commodities that are essential for humans and animals. A very good example of the fulfillment of such conditions is the culturing of algae.

\section{RAW MATERIALS PROCESSED IN BIOREFINERIES}

The most typical sources of biomass for biorefineries include agricultural crops, animal cultures, tree crops and waste from these. Plant biomass is formed as a result of photosynthesis, in which $\mathrm{CO}_{2}$ from the atmosphere is converted into sugar, and by complex metabolic pathways in other more complex compounds such as proteins, fats and carbohydrates. Crops are the main source of biomass because they contain polysaccharides (mainly starch) and oil. However, food products should not be used in the production of chemicals, biofuels and biopolymers for reasons which are discussed in the principles of biorefineries.

Very good raw material for further processing is lignocellulosic biomass which has a capacity of up to $40 \mathrm{t} /$ ha (Aresta et al., 2012). Lignocellulosic materials are dry agricultural residues such as straw and husks, as well as waste wood, waste paper and lignin. In these wastes, the largest fraction is cellulose (40-50\%), and the next are hemicellulose (20-30\%) and lignin (15-20\%). Hemicellulose is the building block of almost all the walls of plant cells. While cellulose is crystalline, hemicellulose has a random, amorphous structure with little strength. Lignin is one of the most common biopolymers on earth, second only to cellulose. Unfortunately, the lignocellulosic wastes currently are almost exclusively used to generate energy (which is called a thermochemical-processing approach), thus losing the most valuable components. Much less frequently a so-called biochemical approach is applied, which is much more advantageous. In this case cellulose and hemicellulose are hydrolysed to produce sugars (mainly glucose (C6-sugar) and xylose (C5-sugar), which are then used as a substrate for fermentation resulting in alcohols and organic acids as well as can be applied in the production of different chemicals: solvents, paints, degreasing substances, cleaning agents, pesticides, drilling muds, modifiers, lubricants, 
greases and fuels. Lignin can be used to produce formaldehyde resins, fuels or carbon fibers. This way of processing is called green biorefineries (Xiu and Shahbazi, 2015). A scheme of lignocellulose processing in biorefineries in shown in Fig 3.

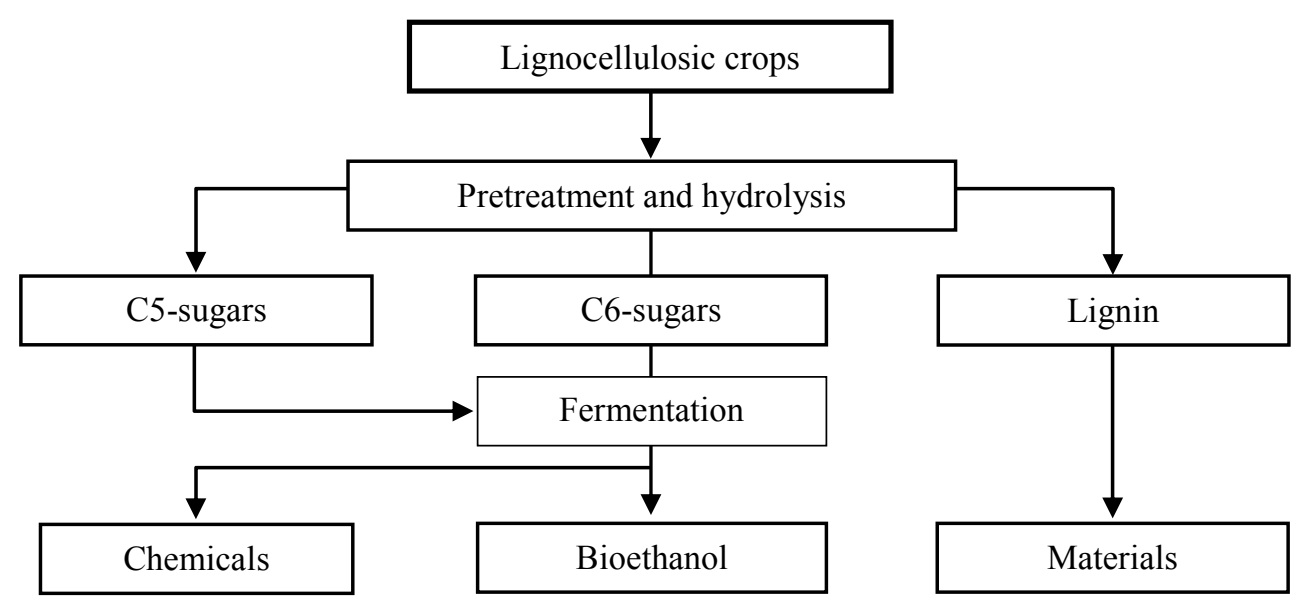

Fig. 3. Biorefineries based on lignocellulosic material (Koltuniewicz, 2014)

In green biorefineries virtually all natural green plants can be used as raw materials, providing that they do not belong to the food sources, as was mentioned previously in basic principles. A lot of valuable organic substances such as: drugs, proteins, free amino acids, organic acids, enzymes, hormones, minerals, dyes and pigments can be obtained in this way. For example, the leafy plant juice is a source for production of lactic acid and its derivatives, amino acids, ethanol and proteins. In the dry residue (after the juice squeezing) levulinic acid is produced but also the green feed pellets, and the synthesis gas and several hydrocarbons (synthetic biofuels). The remains after a substantial conversion are also suitable for biogas production, combined with the generation of electricity and heat (Xiu and Shahbazi, 2015).

Processing of biomass takes place in bioreactors and photobioreactors using suitable and well known unit processes. Production based on culturing, harvesting, various pretreatments, as well as fermentations and separation methods that were described in numerous publications in the field of bioprocess engineering. These methods have long been used in related productive sectors such as manufacturing of pharmaceuticals, chemicals and related services. A specific feature of the production method is the use of living cells of microorganisms and enzymes that must be isolated from the environment in bioreactors, where conditions are carefully controlled. Membrane based hybrid processes create a new unlimited opportunity to separate homogenous as well as heterogeneous mixtures, and can be applied in biorefineries.

\section{APPLICATION OF ALGAE IN BIOREFINERIES}

Algae are the specific microorganisms (prokaryotic or eukaryotic), which are capable of photosynthesis. They can grow quickly, even in difficult conditions and can be characterised by high yields, offering a high content of valuable ingredients, including fats, proteins, polysaccharides and others.

Cultivation of algae fulfills almost all the requirements imposed on biorefineries. A scheme of biorefinery based on algae is shown in Fig 4. Algae are characterised by the highest biomass yield per unit area and do not compete with conventional food crops. They are suitable for processing waste and a variety of water treatments, so they seem to be the most suitable energy source for sustainable 
development. Nowadays, the use of various algae can be found almost in all sectors of human activity (Georgianna and Mayfield, 2012).

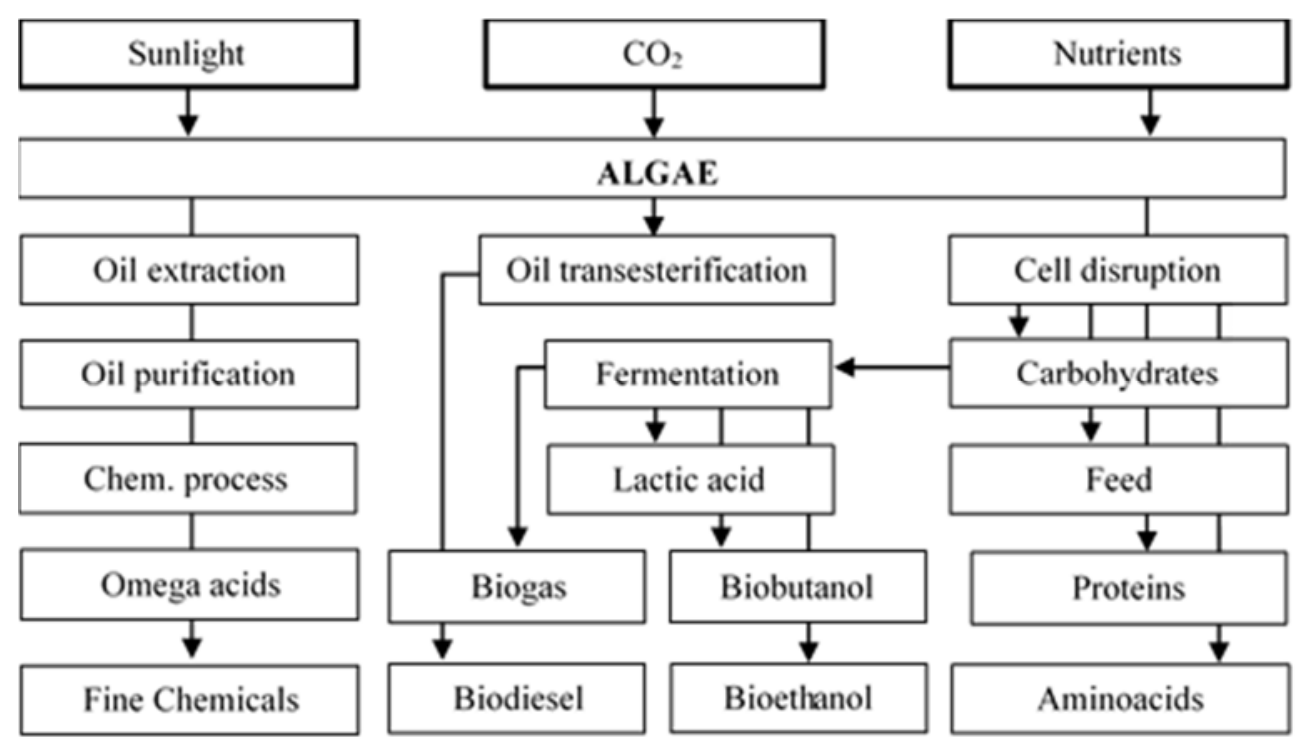

Fig. 4. Scheme of biorefinery based on algae (Koltuniewicz, 2014)

Algae can be cultivated in photobioreactors or in shallow open ponds. In relation to breeding algae in photobioreactors, the efficiency of photosynthesis is less than $10 \%$ since the majority of photon energy is consumed to heat and fluorescence. In the case of open ponds (see Fig. 5), algae can be grown only within limited latitudes, because the temperature range for their crops is very narrow $\left(20-30^{\circ} \mathrm{C}\right)$. Furthermore, several other important conditions should be taken into account, such as phases of light and darkness, $\mathrm{pH}$, salinity, the intensity of aeration and mixing. Some cultures require strict control of process parameters and have to be placed in closed bioreactors.

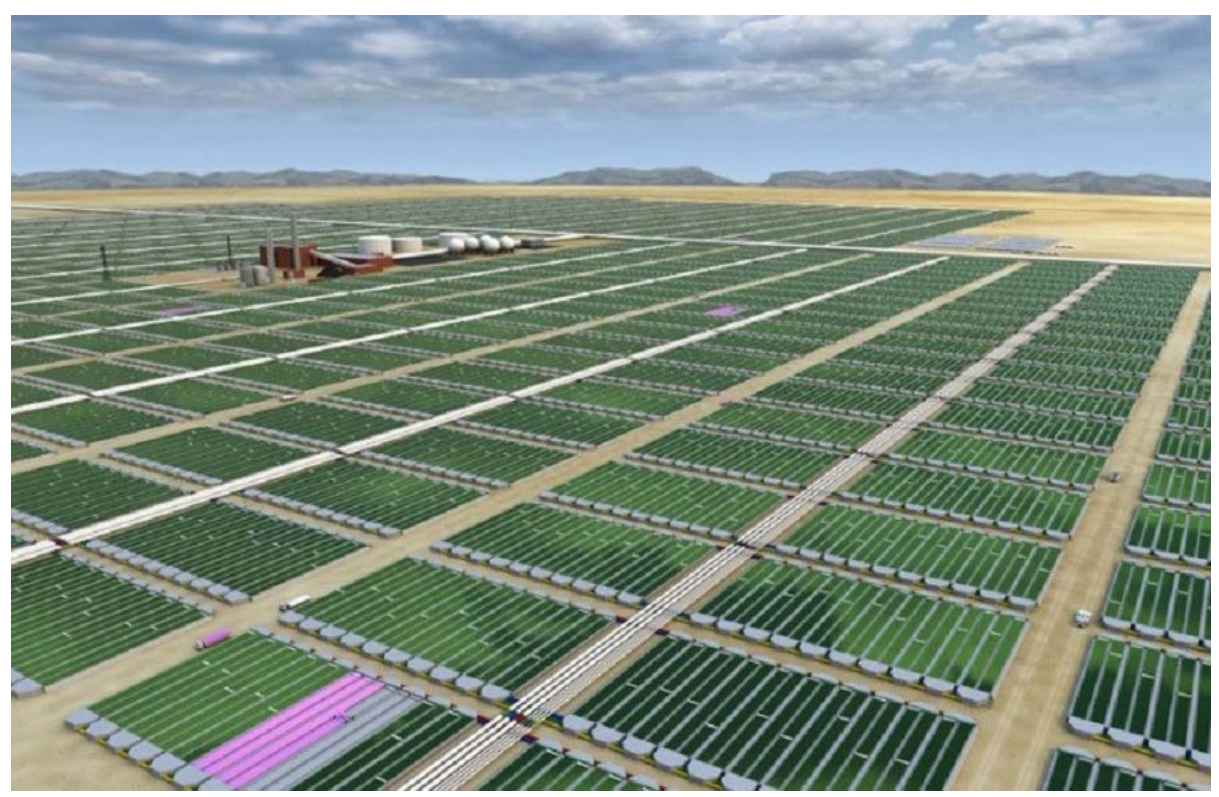

Fig. 5. Algae cultivation in open ponds (photo by Joel Cuello, UANews, 2011)

Recently, the most popular photobioreactors are tubular, annular and flat-plate (Fig. 6) (Singh and Sharma, 2012). The diameters in tubular bioreactors do not exceed $40 \mathrm{~mm}$ and their lengths may be more than $100 \mathrm{~m}$ depending on the required residence time. Their efficiency is much higher than that of other reactors, due to higher concentrations and easier recovery of biomass (Sierra et al., 2008). 
A drawback of tubular configurations is large energy consumption, besides they are more expensive to build, operate and maintain (Borowitzka, 1999). The vertical disposition benefits in the light transfer process and $\mathrm{CO}_{2}$ dispersion by controlling the barbotage system, which enhances productivity and reduces the area applied for cultivation (Cuaresma et al., 2011).
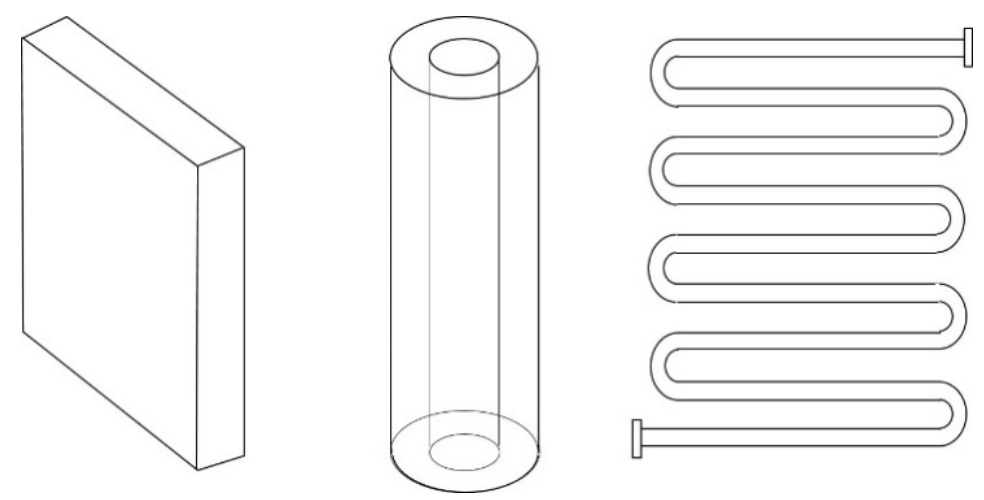

Fig. 6. Three main configurations of photobioreactors: a) plate-frame, b) annular, c) tubular (Koltuniewicz, 2014)

Breeding of algae has long been practiced by many commercial companies which is the evidence of its cost-effectiveness (Frost and Sullivan, 2007). Photobioreactors are used e.g. by: A2BE Carbon Capture, Algae Tec, Bionavitas, Dynamic Biogenics, Greenshift, Green Star and Origin Oil (Oilgae, 2014). Algae can be cultivated in deserts, waste waters and on marine plants. After growing, the next steps in algae processing are drying and extracting of valuable bioactive substances using supercritical fluid extraction process that is efficient, secure, inexpensive and safe for the environment. Aquaculture can have a very positive impact on the environment by removing $\mathrm{CO}_{2}$ from the air and excess nutrients causing eutrophication. Microalgae are a very attractive source of raw materials due to the potential high yields of biomass. Admittedly algae production costs may be higher in comparison with food, but they can achieve high performance (up to $250 \mathrm{t} / \mathrm{ha}$ /year), which is about 15-300 times more than land plants, and gives 10-100 times more fuel per unit area than crops used to the production of second generation biofuels (Greenwell et al., 2009). Various products are obtained from algae in the industry: food products and additives (nutrients, dyes, gels, stabilizers and emulsifiers), cosmetics and pharmaceuticals. Algae can produce different nutrients as: proteins, polyunsaturated fatty acids, pigments and other bioactive compounds, vitamins, enzymes and hormones. Single cell proteins are used as substitutes for protein in human and animal foods. Essential oils can be used for products such as creams, lotions and ointments (Griffiths, 2010). Algae based polyunsaturated fatty acids include: arachidonic acid (ARA, an important omega-6 fatty acid), docosahexaenoic acid (DHA, an omega-3 acid, is an essential part of the human brain, cerebral cortex, skin and retina), gamma linolenic acid (GLA, an organic compound from the group of omega-6, which is a precursor of prostaglandin PGE1 hormonally active arachidonic acid derivative with many biological functions). Algae can produce also flavouring substances as: pyroles, cyclopentenones (Maksymiec et al., 2005), phenols (Li et al., 2007), furans, pyrrolidones, indoles and skatol (Jirásková et al., 2009). In the pharmaceutical industry, algae are useful for the preparation of biologically active compounds used for the production of antioxidants and various antibacterial, antifungal, antiviral, antiprotozoal, antineoplastic, anti-obesity, anti-diabetic and anti-inflammatory agents, and as a support for the immune, cardiovascular and nervous system, and vitamins (Borowitzka, 1986). Additionally, algae are useful in treatment of fibromyalgia, diabetes and hypertension, as well as in skin diseases. Especially Lycophene is a precious algae radical scavenger that reduces the risks of certain cancers (Lintner et al., 2009). Companies involved in the processing of algae for the pharmacological industry are e.g. Rincon Pharmaceuticals and Triton Health. The most promising enzyme from the alga is superoxide dismutase, which is an important antioxidant, and has potent anti-inflammatory activity (Liu et al., 2009). Some of algae show the presence of unique 
haloperoxidases or vanadium bromoperoxidase with high resistance to thermal and chemical denaturation (Lods et al., 2000).

In cosmetics algae are used as a biologically active ingredient of different lotions and creams such as: anti-cellulite, antibacterial, sun protection shaving and hair care, as well as in tooth paste and soaps. In the textile industry, algae are used for the production of oils to lubricate fibers (Solazyme). In the chemical industry algae are used in the production of surfactants, skimmers, inks, resins, chemicals, pigments and dyes. Global production of surfactants was estimated at 12.7 million tons / year in 2012. Microalgal oils are extremely rich in triamines, which can be easily modified to new surfactants. Inks and coatings are made from resins with appropriately selected physical properties, such as rheological, high-gloss, hardness, and scratch resistance. The companies engaged in chemical and cosmetic industries using algae are Algix LLC and Cereplast. In the environment sector, algae are used in wastewater treatment as biofilters, for the treatment of fish ponds and sewage, removal of heavy metals, for the adsorption of metal ions, $\mathrm{CO}_{2}$ capture, as additives to the soil, nutrients, fertilisers and biocides. With algae also building materials, such as composites, substitutes of mortar, brick, concrete, asphalt, and others such as lubricants and paints can be produced. Algae are used also for the production of various energy carriers such as biodiesel, ethanol, methane, hydrogen, gasoline, biobutanol and can be also directly combusted.

\section{MATERIALS AND BIOPOLYMERS}

Renewable sources, such as vegetable fats and oils, starch and biomass can be applied in the production of bioplastics (Chua et al., 1999). Global production capacity for biobased polymers was estimated to be 360 million tons in 2007, with an annual market growth rate of $48 \%$ in Europe and $38 \%$ globally. At present, the following bioplastic types are manufactured: starch-based and cellulose-based plastics, aliphatic polyesters, polylactic acid (PLA) plastics, polyhydroxyalkanoates (PHA), poly-3hydroxybutyrate (PHB), polyamide 11 (PA 11), bio-derived polyethylene and genetically modified bioplastics (Daicel Polymer Ltd., 2012; Tserki et al., 2006). The use of biomass can reduce the costs of polymers production. Biodegradable polymers are mainly produced using starch, but should be based on cellulose and waste materials due to the harmful competition with food production. A good example is DuPont, that produce a conductive polymers called Ligno-Pani, which were originally developed by NASA. Some of biodegradable polymers are even compostable. The prospect of producing bioplastics in transgenic plants may completely alter the environmental consequences of production. Now and in the future, all designed polymers should be biodegradable to meet the demands of sustainable development. Cellulose and cellulose waste are particularly suitable for processing in biorefineries because it is the most popular natural biopolymer on Earth, which is used to produce many goods such as paper, cardboard, bioplastics as cellophane and rayon. Cellulose for industrial use is mainly obtained from wood pulp and cotton. The first commercial textiles from cellulose acetate in fibre form were developed by the Celanese Company in 1924. Cellulose acetate is a cheap cellulosic material of good toughness and is common material in production of membranes for reverse osmosis. Bioplastics from cellulose are most commonly composed of cellulose esters and derivatives, including cellulose acetate butyrate, cellulose propionate and cellulose acetate butyrate. Cellulosic plastics are characterised by good strength, toughness, transparency and high surface gloss. A method of the production of high quality PLA was developed in 1954 in DuPoint Corporation (Lowe, 1954) whilst at the beginning of 90' Cargill Corporation developed a method for the continuous production of this polymer (Gruber et al., 1993). Currently PLA is prepared from corn starch, which in the first step is converted to dextrose. Then, by anaerobic microbial fermentation, lactic acid is obtained, which is converted into cyclic lactide monomer and finally it polymerises to PLA (see Fig. 7). PLA can be easily recycled, because its wastes may be converted back to the lactide and again subjected to polymerisation (Holmgren and Henning, 2004). Easy biodegradability of PLA enables its numerous applications in medicine, for 
example for surgical sutures, pins, suture anchors, plates, screws, and intra-vascular stents, burn dressings and substrates and skin grafts (Ulery et al., 2011). PLA is also suitable for the controlled release of drugs (Ge et al., 2000).

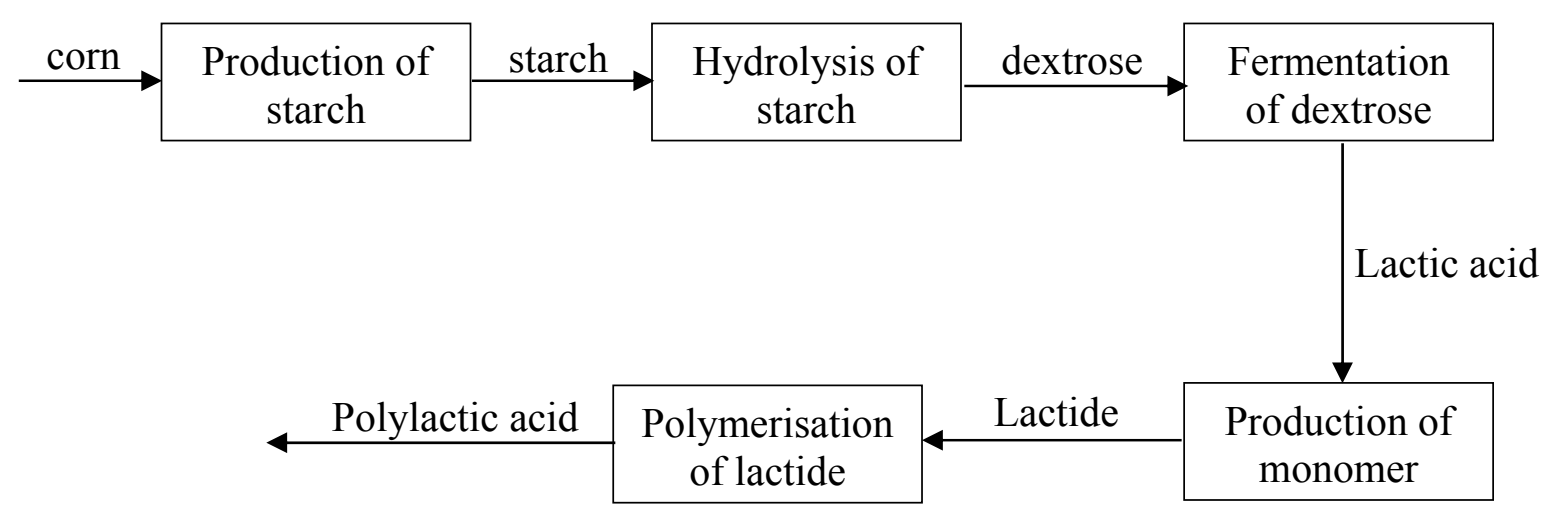

Fig. 7. Schematic diagram of simplified technology for the production of biopolymer of lactic acid, PLA

(Koltuniewicz, 2014)

PHAs are linear polyesters produced in nature by bacterial (e.g. Alcaligenes eutrophus) fermentation of sugar or lipids. PHAs are thermoplastics, have low moisture permeability and are resistant to UV radiation, in contrast to polylactides. More than 150 different monomers can be combined within this family to give materials with extremely different properties (Doi and Steinbuchel, 2002). They are highly biodegradable and can be either thermoplastic or elastomeric materials, with melting points ranging from 40 to $180^{\circ} \mathrm{C}$. $\mathrm{PHB}$, is a biodegradable, biocompatible and thermoplastic polymer from the group of aliphatic polyesters produced by a bacterium Ralstonia eutropha H16. It is often used in medicine. Moreover, it has high mechanical strength, close to that of polypropylene (PP), has a good resistance to moisture, good oxygen permeability, good UV resistance but poor resistance to acids and bases. Production of PHB is based on starch and whey by means of Azotobacter chroococcum and recombinant Escherichia coli, respectively (Kim, 2000). Due to economic reasons in 2004 Metabolix began to produce PHB also from plants (Jacquel et al., 2008). Soybean and linseed oils were used as substrates for monomers to produce elastomers (Hong et al., 2012) and ethylene from bioethanol (KBBE Report, 2010). In the United States, \$ 310 billion was spend on bioplastics in 2002.

\section{ENERGY AND FUELS}

The current production of fuels, such as biodiesel, bioethanol, biobutanol, biogas, biohydrogen etc., from renewable sources is mainly based on sugars and starches of different cereals, maize, sugar cane and beet and various edible oils such as sunflower, soybean, canola, olive oil, avocado trees and peanuts. However, due to lack of food in the world, there is a great interest in the use of renewable nonfood raw materials and agricultural and industrial waste, especially wood. This may be special fastgrowing industrial crops, cellulosic and lignocellulosic waste and inedible oils of different origin, such as: Jaropha oils from trees, waste from sewage treatment plants, fryers and slaughterhouses. For the production of oils, algae are especially attractive in contrast to terrestrial plants, due to their excellent performance and because they are not grown on arable land.

Ethanol is a substrate for the production of biodiesel and used as an additive for fuels and oxidisers, and also can be used as a fuel for vehicles in its pure form. Ethanol is currently produced from the fermentation of starch crops, such as corn or sugar cane. The biorefinery ethanol will be produced mainly from lignocellulose biomass, derived from sources other than food, such as trees and grasses. Biodiesel is the first biofuel and is produced by transesterification of triglycerides from vegetable oils 
and animal fats. It may be used as a fuel for vehicles in its pure form, but now it is generally used only as an additive to reduce emission levels of particles, $\mathrm{CO}$ and hydrocarbons from diesel vehicles. Butanol can replace gasoline without necessary modification of internal engine combustion. It can be produced from green waste by extraction of microbial fermentation products. Technology for the production of biogas is based on different types of waste from the agricultural production of animals, plants and municipal wastewater. Methane, the main component of natural gas can also be produced from algae in different ways, namely, pyrolysis and gasification by anaerobic digestion (Yen and Brune, 2007). Hydrogen is called the most environmentally friendly energy carrier, not a fuel, because in the course of its combustion only water is produced. Currently there are five distinct technologies of hydrogen production such as: direct photolysis, indirect photolysis, photofermentation and dark fermentation. Biohydrogen production can be based on four very different types of microorganisms, i.e. green algae, cyanobacteria, purple non-sulfur bacteria and anaerobic heterotrophic bacteria but it is mainly produced, as a result of action of a dehydrogenase in algae, bacteria and archaea (Hemschemeier et al., 2009). Dehydrogenases are enzymes that convert protons to hydrogen and present high catalytic activity. They are classified as oxidoreductases, which detach hydrogen atoms from a variety of organic compounds found in living organisms (Zaborsky, 2007). Green algae and cyanobacteria also have a significant yield to the end of the uptake of $\mathrm{H}_{2}$, although dehydrogenase responsible for the production of hydrogen has not been identified.

Photo-biological decomposition of water may take place in a closed photobioreactor space containing different mutants and algae Chlamydomonas reinhardtii (Ghirardi et al., 2000). So far, the performance of such a process is small $\left(0.07-0.08 \mathrm{mmol} / 1\right.$ or $\left.1.6-1.81 / \mathrm{m}^{3} \cdot \mathrm{h}\right)$. Enzymatic photolysis with $\mathrm{Fe}$ hydrogenase enzyme takes place under anaerobic conditions (Horner et al., 2000) and is known as direct photolysis. Cyanobacteria can also produce hydrogen by indirect photolysis by means of nitrogenase, which uses photosynthesis to collect gaseous nitrogen while generating $\mathrm{H}_{2}$ (Pinto et al., 2002).

Photofermentation is a process of conversion of organic substrates to bio-hydrogen involving a diverse group of photosynthetic bacteria and enzymatic reactions that are similar to anaerobic metabolism. Only the bacteria Bacillus, Clostridia and Enterobacter can produce $\mathrm{H}_{2}$ in metabolic fermentation in large quantities. These bacteria feed on carbohydrates and are not capable of anaerobic respiration. Dark fermentation differs from photofermentation because it only occurs in the absence of light (Levin et al., 2004). Dark fermentation (Krupp and Widmann, 2009) refers to the production of $\mathrm{H}_{2}$ by various heterotrophic bacteria that may be cultured in a variety of optimal conditions. Unfortunately, in practice not only $\mathrm{H}_{2}$ but also other gases, mainly $\mathrm{CO}_{2}, \mathrm{CH}_{4}$ and volatile fatty acids, are produced depending on the route used for fermentation.

\section{CONCLUSIONS}

Biorefinery development should be done in a sustainable way. A temporary increase in the profitability of the production of fuels and energy cannot be at the expense of the production of any indispensable goods such as food, feed, and cannot be their competitor. Also the development of plantations specifically for biorefineries should not cause losses to crops and other plants and should not be a threat to the health and life either of humans or animals. Long-term use of intensive monocultures and large crops for biorefineries can cause depletion of arable land and eutrophication. This in turn is related to climate change, desertification of soil, diseases and eventually leads to extinction of species in water and on land. Countries should encourage the use of: biomass from industrial waste, agriculture and forestry and the use of algae in various types of bioreactors (open and closed). It is now believed that the problem of commercialisation is limited by economic conditions, as well as difficulties in communication between scientists and engineers (Hallenbeck and Benemann, 2002). Anyway, soon, 
we will certainly be forced to make use only from nature, and therefore we should live in harmony with it. Simply because we have no other choice.

\section{REFERENCES}

Aresta M., Dibenedetto A., Dumeignil F., 2012. Biorefinery: From Biomass to Chemicals and Fuels. DeGruyter.

Biopol, 2009. Final report EU-FP6-project, Deliverable D7.6. Available at: www.biorefinery.nl/fileadmin/biopol/user/documents/PublicDeliverables/BIOPOL_D_7_6_-_Final_240609.pdf.

Borowitzka M.A., 1986. Micro-algae as sources of fine chemicals. Microbiol Sci., 3, 372-375.

Borowitzka M.A., 1999. Commercial production of microalgae: Ponds, tanks, tubes and fermenters. J. Biotechnol., 70, 313-321. DOI: 10.1016/S0079-6352(99)80123-4.

Chua H., Yu P.H., Ma C.K., 1999. Accumulation of biopolymers in activated sludge biomass. Appl. Biochem. Biotechnol., 78, 389-399. DOI: 10.1007/978-1-4612-1604-9_36.

Cuaresma M., Janssen M., Vílchez C., Wijffels R.H., 2011. Horizontal or vertical photobioreactors? How to improve microalgae photosynthetic efficiency. Bioresour. Technol., 102, 5129-5137. DOI: 10.1016/j.biortech.2011.01.078.

Daicel Polymer Ltd., 2012. A new cellulose bioplastics "CELBLEN EC" based on non-edible wood resources. Available at: www.daicelpolymer.com/en/news/2012/121129.html.

Doi Y., Steinbuchel A., 2002. Biopolymers. Vol 3a. Polyesters I: Biological systems and biotechnological production. Wiley-VCH, Weinheim, Germany.

Frost \& Sullivan, 2007. The Impact of green trends in the European Oleochemicals market. Available at: www.frost.com/prod/servlet/market-insight-top.pag?docid=102601717.

Ge H., Hu Y., Yang S., Jiang X., Yang C., 2000. Preparation, characterization, and drug release behaviors of drug-loaded e-Caprolactone/L-Lactide copolymer nanoparticles. J. Appl. Polym. Sci., 75, 874-882. DOI: 10.1002/(SICI)1097-4628(20000214)75:7<874::AID-APP3>3.0.CO;2-G.

Georgianna D.R., Mayfield S.P., 2012. Exploiting diversity and synthetic biology for the production of algal biofuels. Nature, 488, 329-335. DOI: 10.1038/nature11479.

Ghirardi M..L., Zhang L., Lee J.W., Flynn T., Seibert M., Greenbaum E., Melis A., 2000. Microalgae: A green source of renewable $\mathrm{H}_{2}$. Trends Biotech., 18, 506-511. DOI:10.1016/S0167-7799(00)01511-0.

Greenwell H.C., Laurens L.M., Shields R.J., Lovitt R.W., Flynn K.J., 2009. Placing microalgae on the biofuels priority list: A review of the technological challenges. J. Roy. Soc. Interface, 7 (46), 703-726. DOI: 10.1098/rsif.2009.0322.

Griffiths T.W., 2010. Cosmeceuticals: Coming of age. Br. J. Dermatol., 162, 469-470. DOI: 10.1111/j.13652133.2010.09634.x.

Gruber P.R., Hall E.S., Kolstad J.J, Iwen M.L., Benson R.D., Borchardt R.L., 1993. Continuous process for manufacture of lactide polymers with controlled optical purity. U.S. Patent 5,247,058.

Hallenbeck P.C., Benemann J., 2002. Biological hydrogen production: fundamentals and limiting processes. Intl. J. Hydrogen Energ., 27, 1185-1193. DOI: 10.1016/S0360-3199(02)00131-3.

Hemschemeier A., Melis A., Happe T., 2009. Analytical approaches to photobiological hydrogen production in unicellular green algae. Photosynth Res., 102, 523-540. DOI: 10.1007/s11120-009-9415-5.

Holmgren K., Henning D., 2004. Comparison between material and energy recovery of municipal waste from an energy perspective: A study of two Swedish municipalities. Resour. Conserv. Recy. 43, 51-73. DOI: 10.1016/j.resconrec.2004.05.001.

Hong J., Luo Q., Wan X., Petrović Z.S., Shah B.K., 2012. Biopolymers from vegetable oils via catalyst- and solvent-free chemistry: Effects of cross-linking density. Biomacromolecules, 13, 261-266. DOI: $10.1021 / \mathrm{bm} 201554 \mathrm{x}$.

Horner D.S., Foster P.G., Embley T.M., 2000. Iron hydrogenases and the evolution of anaerobic eukaryotes. Mol .Biol. Evol., 17, 1695-1709. DOI: 10.1016/S0968-0004(01)02053-9.

Jacquel N., Lo Ch-W., Wei Y-H., Wu H-S, Wang S.S., 2008. Isolation and purification of bacterial poly(3hydroxyalkanoates). Biochem. Eng. J., 39, 15-27. DOI: 10.1016/j.bej.2007.11.029.

Jirásková D., Poulíčková A., Novák O., Sedláková K., Hradecká V., Strnad M., 2009. High-throughput screening technology for monitoring phytohormone production in microalgae. J. Phycol., 45, 108-118. DOI: 10.1111/j.1529-8817.2008.00615.x. 
KBBE Report, 2010. The knowledge based bio-economy in Europe: Achievements and challenges. Available at: www.kbbe2010.be/en/kbbe2010/programme/kbbe-report.

Kim B.S., 2000. Production of poly(3-hydroxybutyrate) from inexpensive substrates. Enzyme Microb. Tech., 27, 774-777. DOI: 10.1016/S0141-0229(00)00299-4.

Koltuniewicz A.B., 2014. Sustainable process engineering - Prospects and opportunities. DeGruyter.

Koltuniewicz A.B., Drioli E., 2008. Membranes in clean technologies - Theory and practice. WILEY.

Krupp M., Widmann R., 2009. Biohydrogen production by dark fermentation: Experiences of continuous operation in large lab scale. Intl. J. Hydrogen Energy, 34, 4509-4516. DOI: 10.1016/j.ijhydene.2008.10.043.

Levin D.B., Pitt L., Love M., 2004. Biohydrogen production: Prospects and limitations to practical application. Intl. J. Hydrogen Energy, 29, 173-185. DOI: 10.1016/S0360-3199(03)00094-6.

Li H.B., Cheng K.W., Wong C.C., Fan K.W., Chen F., Jiang Y., 2007. Evaluation of antioxidant capacity and total phenolic content of different fractions of selected microalgae. Food Chem., 102, 771-776. DOI: 10.1016/j.foodchem.2006.06.022.

Lintner K., Mas-Chamberlin C., Mondon P., Peschard O., Lamy L., 2009. Cosmeticals and active ingredients. Clin. Dermatol. 27, 461-468. DOI: 10.1016/j.clindermatol.2009.05.009.

Liu J., Gu X., Robbins D., Li G., Shi R., McCord J.M., Zhao Y., 2009. Protandim, a fundamentally new antioxidant approach in chemoprevention using mouse two-stage skin carcinogenesis as a model. PLOS ONE, 4(4), e5284. DOI: 10.1371/journal.pone.0005284.

Lods L.M., Dres C., Johnson C., Scholz D.B., Brooks G.J., 2000. The future of enzymes in cosmetics. Int. J. Cosmetic Sci., 22, 85-94. DOI: 10.1046/j.1467-2494.2000.00012.x.

Maksymiec W., Wianowska D., Dawidowicz A.L., Radkiewicz S., Mardarowicz M., Krupa Z., 2005. The level of jasmonic acid in Arabidopsis thaliana and Phaseolus coccineus plants under heavy metal stress. J. Plant. Physiol., 162, 1338-1346. DOI: 10.1016/j.jplph.2005.01.013.

Oilgae, 2014. Comprehensive report on attractive algae product opportunities - Preview. Available at: www.oilgae.com/ref/report/non-fuel-algae-products.html.

Pinto F.A.L., Troshina O., Lindblad P., 2002. A brief look at three decades of research on cyanobacterial hydrogen evolution. Intl. J. Hydrogen Energy, 27, 1209-1215. DOI: 10.1016/S0360-3199(02)00089-7.

Regulation (EC) No 1334/2008 of the European Parliament and the Council of 16 December 2008 on flavourings and certain food ingredients with flavouring properties for use in and on foods and amending Council Regulation (EEC) No 1601/91, Regulations (EC) No 2232/96 and (EC) No 110/2008 and Directive 2000/13/EC. Official J. European Union, L 354/34 - L 354/50.

Sierra E., Acién F.G., Fernández J.M., García J.L., González C., Molina E., 2008. Characterization of a flat plate photobioreactor for the production of microalgae. Chem. Eng. J., 138, 136-147.DOI: 10.1016/j.cej.2007.06.004.

Singh R.N., Sharma S., 2012. Development of suitable photobioreactor for algae production - A review. Renew. Sustain. Energy Rev., 16, 2347-2353. DOI: 10.1016/j.rser.2012.01.026.

Tserki V., Matzinos P., Pavlidou E., Vachliotis D., Panayiotou C., 2006. Biodegradable aliphatic polyesters. Part I. Properties and biodegradation of poly(butylene succinate-co-butylene adipate). Polym. Degrad. Stabil., 91, 367-376. DOI: 10.1016/j.polymdegradstab.2005.04.035.

UANews, 2011. More Than Mere Pond Scum. Algae could soon become a valuable biofuel resource, according to research at the UA. UANews. Available at: https://uanews.arizona.edu/story/more-mere-pond-scum.

Ulery B.D., Nair L.S., Laurencin C.T., 2011. Biomedical applications of biodegradable polymers. J. Polym. Sci. B. Polym. Phys., 49, 832-864. DOI: 10.1002/polb.22259.

Xiu S., Shahbazi A., 2015. Development of green biorefinery for biomass utilization: A Review. Tr. Ren. Energy, 1, 4-15. DOI:10.17737/tre.2015.1.1.008.

Yen H-W., Brune D.E., 2007. Anaerobic co-digestion of algal sludge and waste paper to produce methane. Bioresource Technol., 98, 130-134. DOI: 10.1016/j.biortech.2005.11.010.

Zaborsky O.R., 2007. BioHydrogen. Springer Science \& Business Media.

Received 26 June 2015

Received in revised form 01 February 2016

Accepted 02 February 2016 